\title{
Political Stability As Important Factor Of Development Of Tourism Destination - A Case study of Lipno nad Vltavou
}

\author{
Jana KALABISOVÁ, Lucie PLZÁKOVÁ \\ ${ }^{1}$ Institute of Hospitality management, Prague, the Czech Republic \\ kalabisovaevsh.cz,plzakova@vsh.cz
}

\begin{abstract}
Lipno nad Vltavou is one of the most dynamically developing municipality in the Czech Republic over the last twenty years. It is evident that the answer to this question consists in rare political stability and suitable and reasonable tourism management. The research question of this article is therefore if other actors in the micro region (so called "Union of Lipno municipalities") perceive the political stability in the area stable and the cooperation within the council as adequate. To answer this question a questionnaire survey with all of 15 municipalities in the Lipno region was a part of a project titled "Development strategy of the territory of the Lipno municipalities" implemented by the Institute of Hospitality Management in Prague in 2016. It was found that all the respondents have a positive statement about the political stability in the micro region and the political stability in the micro region is also perceived as the most important criteria influencing the cooperation within the council. The potential for further development of the micro region is seen by their representatives at first in the development of the tourism; on the contrary, the greatest threat is perceived in high level of bureaucracy, the lack of transport infrastructure, the migration of young people out of the region and a high degree of protection of nature and landscape.
\end{abstract}

Keywords: Lipno nad Vltavou, Political Stability, Tourism Development.

\section{Introduction}

\subsection{Political aspect}

Each tourism destination wants to be a successful and competitive. But what makes a tourism destination successful? There exist many factors which contribute or influence a success of tourism destination. We talk about specific combination of economic, social, political, environmental, technological and other factors which create a specific environment or circumstances for developing a tourism destination. Political factor as a factor of destination development, destination image or destination reputation is mentioned by several authors on the national level from different perspective (e.g. [16]; [8]; [11]). Political stability or instability has not been the focus of interest of any authors on the local or better said at the municipality level. 
During the mid-1970's to early 1980's, tourism systems research boomed, and a plethora of tourism models were presented from both a theoretical basis, and in the context of planning, development, and management [17]. Tourism studies vary extensively in terms of quality and accuracy, and with respect to which aspects of tourism are included. Many authors have focused on evaluation of tourism impacts at the national level, for example Kabak, and Ülengin [10] using environmental indicators, or Lundie, Dwyer, and Forsyth [12] with the use of disaggregation of national accounts. Indicators have become a very important tool and method to measure the impact of tourism at the local level. According with Vehbi [18], an indicator is a quantitative model and a form of information that makes a certain phenomenon perceptible that is not immediately detectable.

There are many authors or institutions that have set up a theoretical approach to indicators, and others who have tried to determine them through practical application. The studies of the European Union [6], the Organization for Economic Co-operation and Development [5] and the World Tourism Organization [19] are commonly known as the most basic approaches. All of these theoretical approaches do not introduce the political indicators. Recently, The European Tourism Indicator System [7] was updated and contains one notion as a lesson learnt from the pilot phases: "Destinations piloting the ETIS have also emphasised the importance of obtaining relevant local political support for implementation and it can be useful to have this commitment publically announced."

\subsection{Used approach and research question}

The Institute of Hospitality Management in Prague was asked to implement a project for the tourism destination of Lipno nad Vltavou. The project named "Measuring the effects of tourism in the tourism destination of Lipno nad Vltavou" was provided by the Municipality of Lipno nad Vltavou and Lipensko, Ltd.

The main objectives of the project were to:

- determine the way of regular measurement of tourism effects and trends for the municipality of Lipno nad Vltavou,

- and determine the type, frequency and form of data collection.

- It is also important to determine the research questions of this project because there is a direct link with the research question of this article. These questions were to:

- assess whether there was or could be another way of alleviating the economic backwardness of the municipality than through the development of tourism,

- improve the current state of tourism in the municipality.

It was found that the municipality had no other choice how to develop the area that through the tourism. The unique current situation of this destination opened a new and fundamental question - what are the factors of such unique situation in the tourism sector? It is evident that the answer to this question consists in rare political stability and suitable and reasonable tourism management. This fact guided the authors to a question if other authorities in the micro region see it in the same light. Therefore, the research question of this article is if other actors in the micro region (so called "Union 
of Lipno municipalities") perceive the political stability in the area stable and the cooperation within the council as adequate. The importance of the suitable tourism management has been already mentioned by many authors (e.g. [1]; [2]; [3]; [9], [14]; [15]), while the political stability has not been a subject of this attention.

\subsection{Data collection}

To answer the research question, a questionnaire survey was implemented as a part of a project titled "Development strategy of the territory of the Lipno municipalities" prepared by The Institute of Hospitality Management in Prague in 2016. The main objective of this project was to elaborate a strategy for the development of the area of member municipalities of the Lipno Municipal Association. The questionnaire survey was attended by all 15 municipalities in the Lipno region, which have an impact on the formation of a tourist destination - Lipno. Other data were collected from the Czech Statistical Office and other institution providing tourism statistics as Monitor an information portal of the Ministry of Finance that provides free access to budgetary and accounting information at all levels of government and self-government.

\section{Results}

\subsection{Destination Lipno nad Vltavou}

Lipno nad Vltavou is very important tourism destination in the Czech Republic over the last twenty years. The main motive for the development of the village was tourism, because:

- it has a strategic position (it is not located in a specially protected area),

- it was built as a special purpose estate (formerly builders of the dam, nowadays holidaymakers),

- it does not show any fluctuations in the activities of the municipality and has a significant investor (Lipno Servis).

More than twenty years ago, the village of Lipno nad Vltavou decided to go towards the development of tourism and the improvement of the services provided. In 2012, Lipno nad Vltavou won the Best of Realty award for the strategic and territorial development of the municipality through tourism. At the same time, the newly built barrier-free Treetop Walkway became a tourist novel of the summer season of 2012 . The prestigious European award in the seventh edition of the European Commission EDEN (European Destinations of Excellence) project was awarded to Lipno nad Vltavou in 2013 along with other eighteen successful European regions they also target handicapped visitors and tourists.

As it was stated before, the destination Lipno nad Vltavou is politically stable. Average attendance of residents in elections is $63.9 \%$, and there are only two political parties in the Municipality Council - one party without political affiliation and the Communist Party of Bohemia and Moravia (the latter has had only 1 member for two 
election periods). The total number of members in the Municipality Council is seven. The share of new members in each new election period is the most frequently $57 \%$, with the exception of 2002 when it was only $14 \%$. The mayor of the Lipno municipality has been the same since 1990 .

\subsection{Results - Destination Statistics}

The municipality of Lipno nad Vltavou registered 27 collective accommodation establishments (CAE) with 3283 beds in 2016 (according to the source of the Czech Statistical Office, but the municipality itself registers $54 \mathrm{CAE}$ ). Including the individual accommodation facilities, the accommodation capacity is even higher, reaching 59 units with 286 beds, according to the statistics of the municipality. In the CAE, 91 210 guests were accommodated in 2016, of which $67 \%$ of the residents. They spent 405122 nights in the destination with average stay of 4.4 nights. There are 662 inhabitants in the monitored village. It can be stated from the quoted statistics that Lipno nad Vltavou is a hyper-tourist center of tourism depend on the value of the Defert function is 525.5.

The development of basic indicators over time can be responsibly evaluated for the period of 2012-2016, as in 2012 the Czech Statistical Office published the so-called CENSUS - the actual state of the monitored indicators. For this reason, the data after 2012 are not comparable to the data in the period 2000-2011. The data are not available for the year 2012, respectively the data are in the regime "confidential data" (see Table 1). The change in the methodology can be seen especially in the number of overnight stays (Fig. 1).

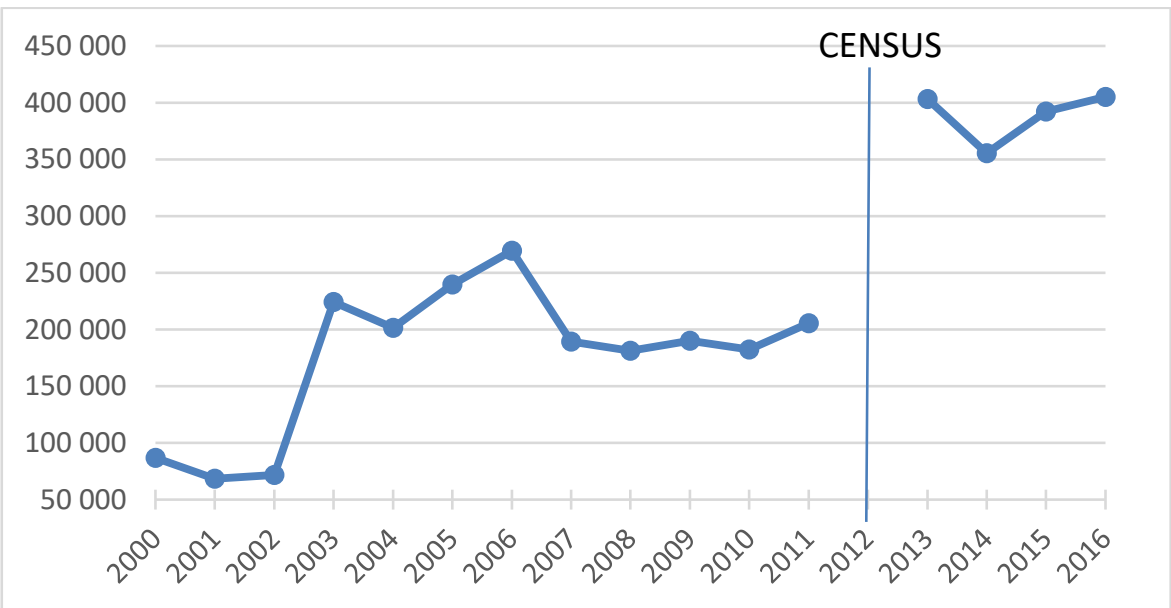

Fig. 1. Number of overnights 2000-2016,[4]

The Czech Statistical Office announced in 2012 and 2013 the percentage of the occupancy of bed capacity in selected municipalities in the Czech Republic. The average occupancy of beds in these years in Lipno nad Vltavou was $19.5 \%$ in CAE, 
while the average for the Czech Republic in 2013 was $34.8 \%$. Lipno is a place with a higher proportion of individual accommodation and apartment apartments, which are not included in the CAE category.

Table 1. Tourism Statistics of Lipno nad Vltavou, 2000-2016, [4]

\begin{tabular}{lccccc}
\hline Year & $\begin{array}{l}\text { Number of } \\
\text { guests } \\
\text { arrivals }\end{array}$ & $\begin{array}{l}\text { Residents } \\
(\%)\end{array}$ & $\begin{array}{l}\text { Number of } \\
\text { overnight } \\
\text { stays }\end{array}$ & $\begin{array}{l}\text { Number of } \\
\text { overnight } \\
\text { stays (\%) }\end{array}$ & $\begin{array}{l}\text { Average } \\
\text { overnight } \\
\text { stays }\end{array}$ \\
\hline 2000 & 22588 & $78 \%$ & 86913 & $81 \%$ & 3.8 \\
2001 & 20025 & $78 \%$ & 68421 & $83 \%$ & 3.4 \\
2002 & 20925 & $76 \%$ & 71874 & $79 \%$ & 3.4 \\
2003 & 43999 & $58 \%$ & 224427 & $44 \%$ & 5.1 \\
2004 & 41272 & $46 \%$ & 201349 & $34 \%$ & 4.9 \\
2005 & 40503 & $39 \%$ & 239860 & $30 \%$ & 5.9 \\
2006 & 67022 & $47 \%$ & 269414 & $37 \%$ & 4 \\
2007 & 34589 & $37 \%$ & 189427 & $26 \%$ & 5.5 \\
2008 & 30760 & $36 \%$ & 181159 & $22 \%$ & 5.9 \\
2009 & 37344 & $46 \%$ & 189997 & $29 \%$ & 5.1 \\
2010 & 34149 & $52 \%$ & 182211 & $36 \%$ & 5.3 \\
2011 & 43306 & $53 \%$ & 205482 & $40 \%$ & 4.7 \\
2012 & i.d. & i.d. & i.d. & i.d. & i.d. \\
2013 & 88678 & $66 \%$ & 403132 & $51 \%$ & 4.5 \\
2014 & 81951 & $65 \%$ & 355596 & $50 \%$ & 4.3 \\
2015 & 91086 & $71 \%$ & 392052 & $59 \%$ & 4.3 \\
2016 & 91210 & $67 \%$ & 405122 & $56 \%$ & 4.4 \\
\hline
\end{tabular}

Note: i.d. - individual or confidential data (explained above Fig. 1)

Other tourism statistics also testify a unique position of the destination of Lipno nad Vltavou. There are two main tourism fees - local accommodation capacity fee and local spa or recreational stay fee. Given that tracking tourism statistics is usually very problematic and often inaccessible, these statistics are an important indicator of the importance of tourism in a given location.

Lipno nad Vltavou was a subject of a comparison with other communities with similar number of inhabitants (501-1000 inhabitants) in the total volume of local accommodation capacity fee and local spa and recreational stay fee (measured in the CZK). It was found that in 2000 the destination had occupied tenth position in the total volume of local accommodation capacity fee out of the total number of municipalities and from 2004 to 2012 occupied second place. Regarding the ranking for the spa and recreational stay fee, Lipno nad Vltavou occupied tenth position out of the total number of municipalities in 2000, between 2005-2007 and in 2009 improved its position to the second place and in 2008 and between 2010-2013 was on the forth place of all the municipalities. 
Table 2. The amount of selected local fees in Lipno nad Vltavou in 2000 - 2016 in CZK [13]

\begin{tabular}{lccl}
\hline Year & $\begin{array}{l}\text { Local Accommodation } \\
\text { Capacity Fee }\end{array}$ & $\begin{array}{l}\text { Local Spa or Recreational } \\
\text { Stay Fee }\end{array}$ & In Total \\
\hline 2000 & 127020 & 587390 & 714410 \\
2001 & 201140 & 864640 & 1065780 \\
2002 & 217560 & 955610 & 1173170 \\
2003 & 320580 & 1853160 & 2173740 \\
2004 & 705840 & 2456430 & 3162270 \\
2005 & 819560 & 2553840 & 3373400 \\
2006 & 921660 & 2717820 & 3639480 \\
2007 & 910860 & 2684680 & 3595540 \\
2008 & 1123850 & 3275490 & 4399340 \\
2009 & 1231860 & 3458180 & 4690040 \\
2010 & 1449020 & 3997740 & 5446760 \\
2011 & 1447830 & 3736350 & 5184180 \\
2012 & 1489780 & 3855310 & 5345090 \\
2013 & 1556895 & 4139072 & 5695967 \\
2014 & 1547319 & 4149375 & 5696694 \\
2015 & 1660916 & 4389089 & 6050005 \\
2016 & 1750186 & 4540434 & 6290620 \\
In Total & 17481876 & 50214610 & 67696486 \\
\hline
\end{tabular}

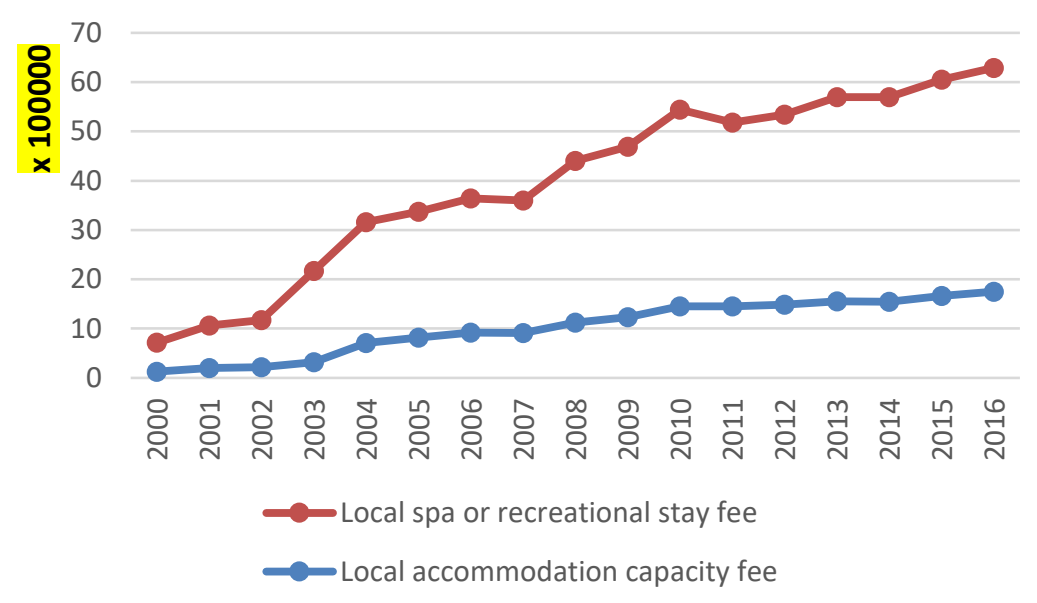

Fig. 2. Development of revenues of local fees directly connected with tourism in Lipno nad Vltavou [13]

Revenue from both local taxes directly associated with tourism is increasing over time period (Table 2, Figure 2). The local fee from the accommodation capacity has 
increased almost 14 times since 2000 and the local spa or recreational stay fee almost 8 times. As shown in Table 3, the revenues from both local fees have accounted for $13 \%$ of the total income of the municipality with fluctuations in individual years in total over the past 7 years.

Table 3. The amount of selected local fees in Lipno nad Vltavou in 2000 - 2016 in CZK [13]

\begin{tabular}{llll}
\hline Year & $\begin{array}{l}\text { Total both fee } \\
\text { in CZK }\end{array}$ & $\begin{array}{l}\text { Total municipality } \\
\text { revenue in CZK }\end{array}$ & \% rates \\
\hline 2010 & 5446760 & 49268790 & $11.06 \%$ \\
2011 & 5184180 & 60237948 & $8.61 \%$ \\
2012 & 5345090 & 43350743 & $12.33 \%$ \\
2013 & 5695967 & 35130587 & $16.21 \%$ \\
2014 & 5696694 & 33679517 & $16.91 \%$ \\
2015 & 6050005 & 42584924 & $14.21 \%$ \\
2016 & 6290620 & 41080898 & $15.31 \%$ \\
Total & 39709316 & 305333407 & $13.01 \%$ \\
\hline
\end{tabular}

\subsection{Survey Results}

This capture introduces the results of the survey in the micro region of Lipensko. As it was stated before, we expect that political stability is a very important factor of the involvement of any tourism destination.

The importance of political stability as an important factor in the formation and direction of the municipality was reflected in the initial question, where $18,4 \%$ of respondents stated political stability as a strong factor of this destination. The potential for further development of the micro region is seen by their representatives at first in the development of the tourism; on the contrary, the greatest threat is perceived in high level of bureaucracy, the lack of transport infrastructure, the migration of young people out of the region and a high degree of protection of nature and landscape.

In direct confrontation with the factor of political stability in the micro region, the outputs mentioned below were identified. It was found that the community supports the community-led local development $-73 \%$ of the respondents agree with this statement and $27 \%$ do not support this statement. 


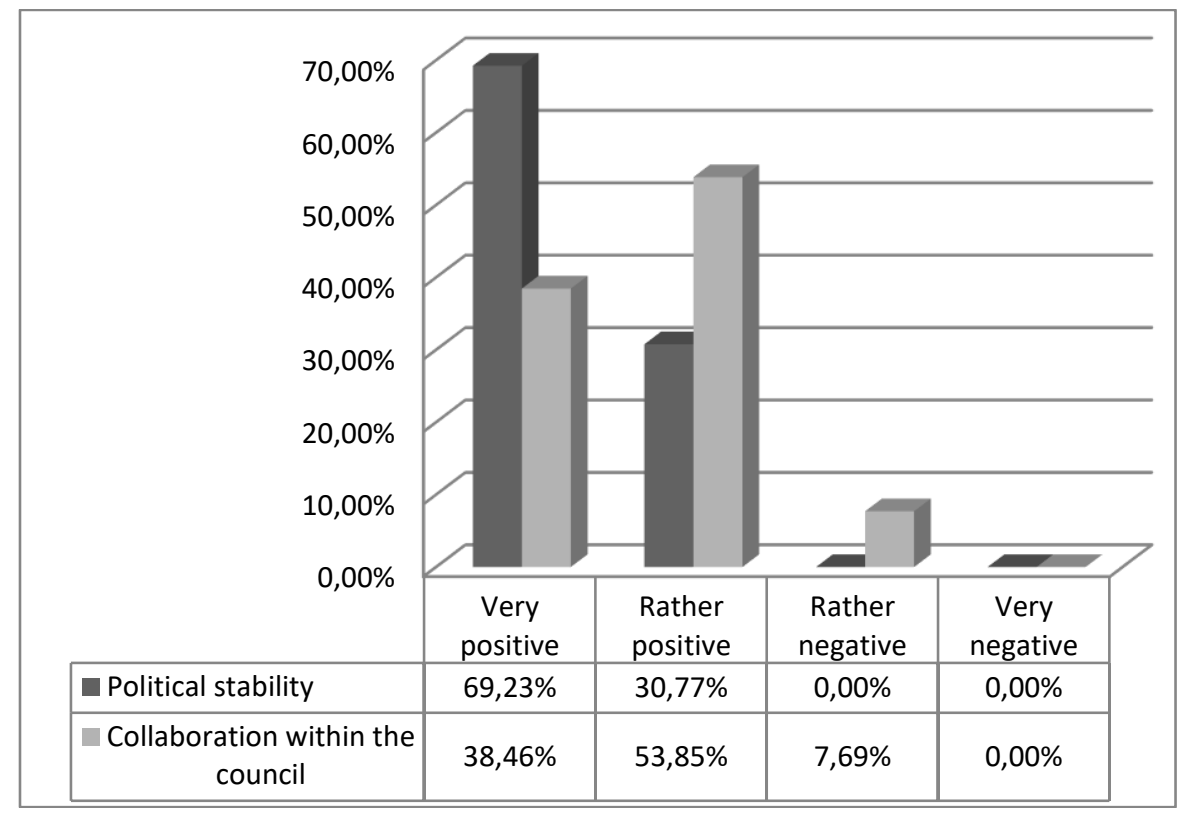

Fig. 3. Survey results - political stability and collaboration within the council

Figure 3 describes the results regarding the political stability and collaboration within the council. The majority of respondents (almost $70 \%$ ) have a very positive statement about the political stability in the micro region; nevertheless the collaboration within the council is evaluated by the majority $(54 \%)$ as rather positive.

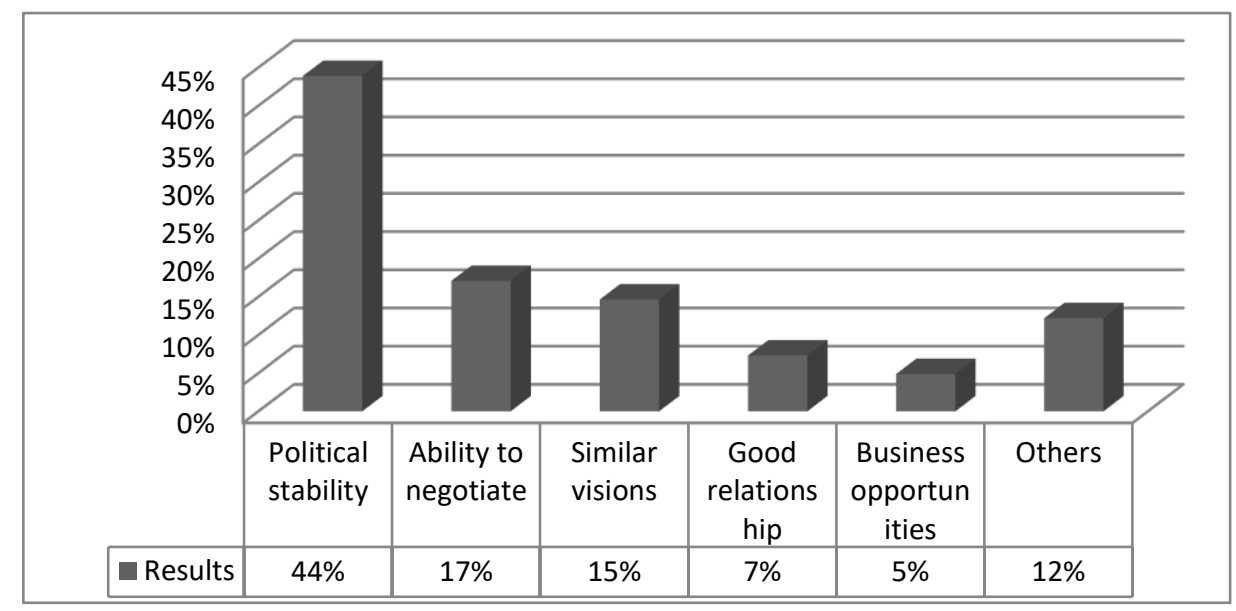

Fig. 4. Survey results - Criteria influencing the cooperation within the council

Criteria influencing the cooperation within the council are a subject of the Figure 4. The political stability is perceived as a major criterion influencing the overall 
cooperation (44\%). Other important criteria are ability to negotiate and similar visions.

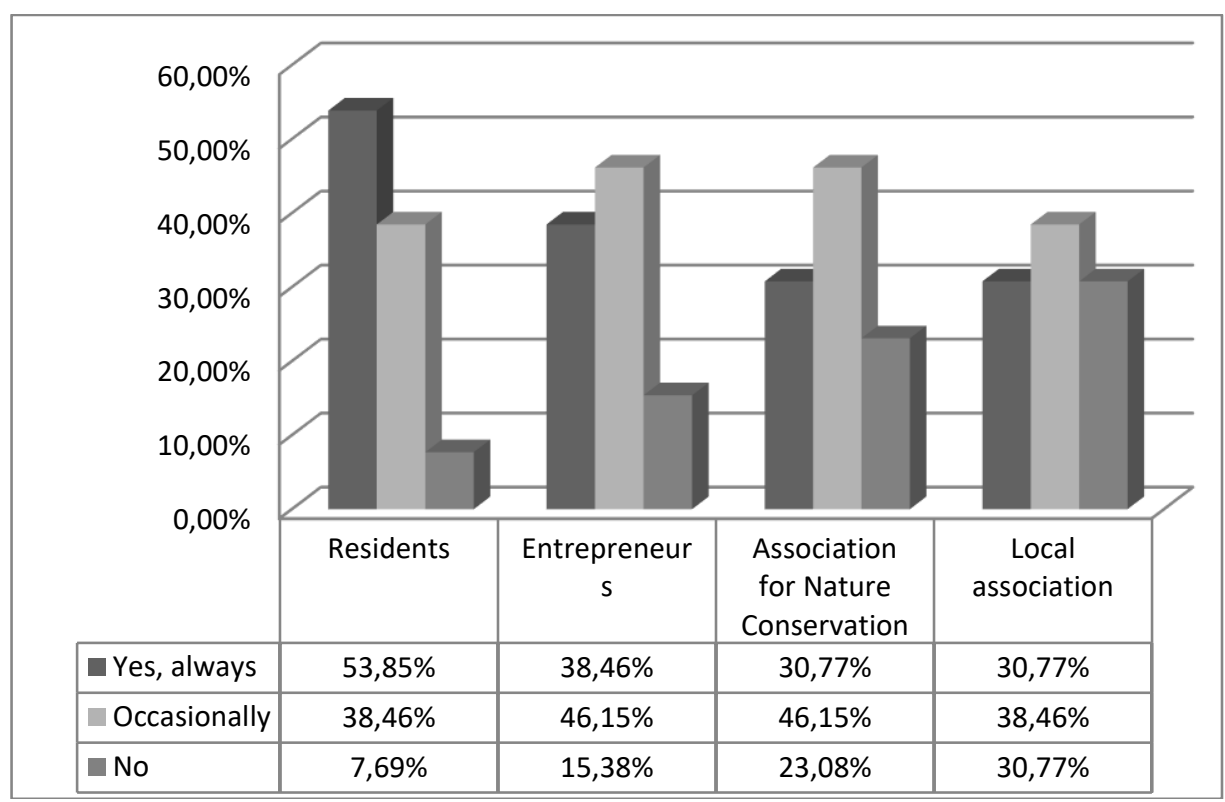

Fig. 5. Survey results - Involvement in decision making

The last Figure 5 describes the involvement of other stakeholders in the decision making in the area. The majority of residents are always involved in this process (54\%), nevertheless entrepreneurs, association for nature conservation and other local associations are involved rather occasionally but their involvement is the overall decision making is rather high (entrepreneurs - 85\%, association for nature conservation $-77 \%$ and other local associations $-70 \%$ ).

\section{Conclusion}

Lipno nad Vltavou is one of the most dynamically developing municipalities in the Czech Republic over the last twenty years. The main motive for the development of the village was tourism, because the destination it is not located in a specially protected area, it was built as a special purpose estate and especially because it does not show any fluctuations in the political stability. The mayor of Lipno nad Vltavou is in function from 1991, it means 26 years, what can be called as a miracle in the conditions of the Czech Republic.

The intensity of the tourism activity is reflected by the statistics. It can be stated from the quoted statistics that Lipno nad Vltavou is a hyper-tourist canter of tourism and the value of the Defert function is 525.5. Revenue from both local taxes directly associated with tourism is increasing over time period (Table 2, Figure 2). The local 
fee from the accommodation capacity has increased almost 14 times since 2000 and the local spa or recreational stay fee almost 8 times. As shown in Table 3, the revenues from both local fees have accounted for $13 \%$ of the total income of the municipality with fluctuations in individual years in total over the past 7 years.

The research question of this article was if other actors in the micro region (so called "Union of Lipno municipalities") perceived the political stability in the area stable and the cooperation within the council as adequate. The results of the survey in the micro region of Lipensko found that the community supports the community-led local development $-73 \%$ of the respondents agreed with this statement and $27 \%$ did not support this statement. All the respondents (100\%) have a positive statement about the political stability in the micro region (69\% very positive and $31 \%$ rather positive) and the collaboration within the council is evaluated by $93 \%$ as positive( $39 \%$ as very positive and $54 \%$ as rather positive). Regarding the criteria influencing the cooperation within the council - the majority of respondents (almost $70 \%$ ) have a very positive statement about the political stability in the micro region; nevertheless the collaboration within the council is evaluated by the majority (54\%) as rather positive. It was also found that the political stability is perceived as a major criterion influencing the overall cooperation (44\%).

Due to this exemplary development of a tourism destination, Lipno was a winner a number of awards. In 2012, Lipno nad Vltavou won the Best of Realty award for the strategic and territorial development of the municipality through tourism. At the same time, the newly built barrier-free Treetop Walkway became a tourist novel of the summer season of 2012. The prestigious European award in the seventh edition of the European Commission EDEN (European Destinations of Excellence) project was awarded to Lipno nad Vltavou in 2013 along with other eighteen successful European regions they also target handicapped visitors and tourists.

The potential for further development of the micro region is seen by their representatives at first in the development of the tourism; on the contrary, the greatest threat is perceived in high level of bureaucracy, the lack of transport infrastructure, the migration of young people out of the region and a high degree of protection of nature and landscape.

The indicators were mentioned in the introduction part as a tool that could help in the management of a tourism destination. The next research will be focused on the political stability in other municipalities or tourism destinations with regard to include a political indicator in methodical approaches.

\section{References}

1. Beritelli, P., Bieger, T.: From destination governance to destination leadership - defining and exploring the significance with the help of a systematic perspective. Tourism Review 69/1, 25-46 (2014).

2. Bieger, T.: Managamnet von Destinationen. Oldenbourg Wissenchaftsverlag GmbH, München (2005). 
3. Bornhorst, T., Ritchie, B., Sheehan, L.: Determinants of tourism success for DMOs \& destinations: An empirici examination of stakeholders' perspectives In Tourism Management 31, 572-589 (2010).

4. Czech Statistical Office (CZSO): Public database, 2017, https://vdb.czso.cz/vdbvo2/faces/cs/index.jsf?page=statistiky\#katalog=31742, last accessed 2017/11/24.

5. Dupeyras, A., MacCallum, N.: Indicators for Measuring Competitiveness in Tourism: A Guidance Document, OECD Tourism Papers, OECD Publishing, (February, 2013).

6. European Union (EU): The European Tourism Indicator System, TOOLKIT, For Sustainable Destinations, DG Enterprise and Industry, European Union (February 2013).

7. European Union (EU): The European Tourism Indicator System, ETIS toolkit for sustainable destination management, European Commission, European Union (March 2016).

8. Hall, C., M.: Tourism Planning: Policy. Processes and Relationship 2nd ed., Pearson, Essex (2008).

9. Hall, D., Richards, G.: Tourism and sustainable Community Development, Routledge, New York, 2003.

10. Kabak, Ö., Ülengin, F.: A New Perspective for Assessing the Sustainability of Countries, Journal of Transnational Management 12(4), 3-32 (2007).

11. Kant, I.: Fundamental Principles of the Metaphysics of Morals, Book Jungle, (2008).

12. Lundie, S., Dwyer, L., Forsyth, P.: Environmental-Economic Measures of Tourism Yield, Journal of Sustainable Tourism 15(5), 503-519, Ipswich (2007)

13. Ministry of Finance (MF): MONITOR, 2017, http://monitor.statnipokladna.cz/2016/, last accessed 2017/10/27.

14. Pechlaner, H., Kozak, M., Volgger, M.: Destination leadership: a new paragum for tourist destinations? Tourism Review 69/1, 1-9 (2014).

15. Petrickova, L., Tittelbachova, S.: Přístupy k řízení destinace cestovního ruchu v ČR (Approaches to the management of tourism destination in the Czech Republic), In Jedlička, P. (ed) Hradec Economic Days, pp. 227-236, GAUDEAUMUS, University of Hradec Králové (2012).

16. Poon, A.: Best Practice Destination Management: Lessons from the Leaders in Conrady. In: R. and Buck, M. (eds.), Trends and Issues in Global Tourism, Springer-Verlag Berlin Heidelberg, (2010)

17. Scarpino, M.: Tourism systems: An analysis of the literature for improved sub-national development, Cooperative Research Center in Tourism (2011), http://www.tourgune.org/uploads/tinymce/filemanager/ConferenciaTourismSystems_Subn tlDevpmt_Shelly072010.pdf, last accessed 2011/10/29.

18. Vehbi, B., O.: A Model for Assessing the Level of Tourism Impacts and Sustainability of Coastal Cities, Strategies for Tourism Industry - Micro and Macro Perspectives, Murat Kasimoglu and Handan Aydin (Ed.), ISBN: 978-953-51-0566-4, (2012), InTech, http://www.intechopen.com/books/strategies-fortourism-industry-micro-and-macroperspectives/a-model-for-assessing-the-level-of-tourism-impacts-andsustainability-ofcoastal-cities, last accessed 2013/11/22.

19. World Tourism Organization (UNWTO): Indicators of Sustainable Development for Tourism Destinations, A Guidebook, World Tourism Organization, http://mekongtourism.org/website/wp-content/uploads/downloads/2011/02/Indicators-ofSustainable-Development-for-Tourism-Destinations-A-Guide-Book-by-UNWTO.pdf, last accessed 2013/12/12. 